\title{
Library and Information Science Education in India with Special Reference to Bhopal City
}

\author{
Dr. Sunita $\mathrm{P}^{1^{*}}$, Riyazat Shah Khan ${ }^{2}$ \\ 1Department of Library and Information Science RNTU Bhopal \\ ${ }^{2}$ Research Scholar Library and Information Science RNTU Bhopal \\ ${ }^{*}$ Corresponding Author \\ Dr. Sunita P \\ Article History \\ Received: 19.09.2019 \\ Accepted: 02.10.2019 \\ Published: 11.11.2019
}

\begin{abstract}
This paper sketches the emergence of library and information science (LIS) education in India with a special reference to Bhopal M.P. It describes the current status, as well as the historical framework on LIS education in India in general and M.P in particular. Many universities and institutions have changed the nomenclature of LIS program, revised the curriculum, shifted from certificate course to master degree program to research study, and international collaboration. It is observed that many LIS schools have changed their curricula from minor tinkering to full revision, from traditional course to digital course. LIS schools opened-up for more interdisciplinary, more practical/practice oriented rather than theoretical classes, and also come forward for international collaboration. But, some of the LIS schools still suffer for their existence due to traditional course curricula, lack of infrastructure, lack of computer lab, and lack of teaching faculty and staff.
\end{abstract}

Keywords: LIS Education, Professional study, Bhopal M.P.

\section{INTRODUCTION}

\section{Library and Information Science Education in India}

In the early $19^{\text {th }}$ Century, young people learned librarianship by working under the more experienced practitioners. But, gradually the tasks performed by librarians became more complex and more dependent on technology. As a result, the study of library science has moved from the work-setting to professional schools in Universities. The first ever library school was started by Melvil Dewey in USA in 1887 at Columbia College (now Columbia University). In 1889 the programme moved to the New York State Library in Albany when Dewey became the Director there. The success of Dewey's training programme and the publication of Training for Library Service, a book by the economist Charles Williamson in 1923, led other universities, institutes of technology, and large public libraries to establish their own professional degree programmes in library science.

\section{Presently the following LIS courses are available in India /BLIS (Bachelor Degree in Library and Information Science) - \\ M.Lib.Sc. /MLIS (Master Degree in Library and Information Science) - PGDLAN (Post Graduate Diploma in Library Automation and Networking) - M.Phil (Master of Philosophy) in Library and Information Science - Ph.D (Doctor of Philosophy) in Library and Information Science - D.Litt in Library and Information Science}

Certificate course in Library and Information Science (C.Lib.Sc) - Diploma in Library and Information Science - B.Lib.Sc

Copyright @ 2019: This is an open-access article distributed under the terms of the Creative Commons Attribution license which permits unrestricted use, distribution, and reproduction in any medium for non commercial use (NonCommercial, or CC-BY-NC) provided the original author and source are credited. 
Table-1: Institutions Offering LIS Education in India Government Institutions

\begin{tabular}{|c|c|}
\hline Central Government Institutions & Courses offered \\
\hline Aligarh Muslim University, Uttar Pradesh & BLISc, MLISc, Ph.D. \\
\hline Assam University, Assam & Integrated MLISc, MPhil, Ph.D. \\
\hline $\begin{array}{l}\text { Babasaheb Bhimrao Ambedkar University, } \\
\text { Uttar Pradesh }\end{array}$ & Integrated MLISc \\
\hline Banaras Hindu University, Uttar Praedsh & MLISc, M.A. in Manuscripto-logy, Ph.D. \\
\hline Central University of Gujrat, Gujarat & M.L.I.Sc. \\
\hline Central University of Haryana, Haryana & M.L.I.Sc \\
\hline $\begin{array}{l}\text { Central University of Himachal Pradesh, Himachal } \\
\text { Pradesh }\end{array}$ & Integrated M.L.I.Sc \\
\hline Delhi University, Delhi & B.L.I.Sc., MLISc, MPhil, Ph.D. \\
\hline Dr Harisingh Gour Vishwavidyalaya, Madhya Pradesh & BLISc, MLISc, Ph.D. \\
\hline Guru Ghasidas Vishwavidyalaya, Bilaspur, Chhattisgarh & $\begin{array}{l}\text { 5-Year Integrated UG/ PG Programme with exit option on completion of } 3 \\
\text { years UG Programme, BLISc, MLISc, Ph.D. }\end{array}$ \\
\hline $\begin{array}{l}\text { Indian Statistical Institute(Documentation Research \& } \\
\text { Training Centre), Karnataka }\end{array}$ & MSLIS, Research Programmes \\
\hline Indira Gandhi National Open University, New Delhi & PGDLAN, BLISc, MLISc, Ph.D. \\
\hline Jamia Mallia Islamia, New Delhi & B.L.I.Sc. \\
\hline Mahatma Gandhi Central University, Bihar & Diploma in Lib Sc, Diploma in Lib \& Inf. Sc., B.L.I.Sc., M.L.I.Sc. MPhil \\
\hline Manipur University, Imphal & Integrated MLISc, Ph.D. \\
\hline Mizoram University & Integrated MLISc, MPhil, Ph.D. \\
\hline North Eastern Hill University & Integrated MLISc, Ph.D. \\
\hline Pondicherry University, Pondicherry & PGDLAN, Integrated MLISc, Ph.D. \\
\hline Tripura University, Tripura & Integrated MLISc \\
\hline
\end{tabular}

LIS Departments in the college of Bhopal .A study Investigators have made a humble attempt to visit the LIS department of Bhopal colleges both Private and semi govt and collected the available information and presented in the table (2).

Table-2

\begin{tabular}{|l|l|l|l|l|}
\hline Type of College & Private & Private & Semi Private & Private \\
\hline Teaching Staff & $1+3$ Female & $2 \mathrm{~F}$ & $2+4$ & $1+1$ \\
\hline Supporting Staff & 1 & 1 & 1 & - \\
\hline Courses Offered & UG \& PG & UG \& PG & UG & UG \& PG \\
\hline $\begin{array}{l}\text { Using in teaching E Resources } \\
\text { /Traditional }\end{array}$ & E-Resources & Both & Traditional & Traditional \\
\hline Books & 80 & 100 & 1220 & 500 \\
\hline Journal Information & 2 & 1 & 3 & 1 \\
\hline $\begin{array}{l}\text { Equipment information DDC ,Colon } \\
\text { Available }\end{array}$ & Yes & Yes & Yes & Yes \\
\hline Medium of Teaching & Bi Lingual & Hindi & Hindi & Hindi \\
\hline Research Publications information & Yes & Nil & Nil & Nil \\
\hline No.Of Student UG & 15 & 33 & 30 & 11 \\
\hline PG & 12 & 20 & NA & 4 \\
\hline
\end{tabular}

The above table indicates that the LIS Departments of Semi private college is more informative as compared to other three. However the investigators found that the fees structure of this course is very low Hindi medium students are more interested to get admission in these courses, which obstruct the availability latest information on LIS education. The participants in this study also mentioned problems with technology in the school. The biggest constraint identified was the lack of funding for updated equipment and adequate access to equipment. Additionally, several of the participants alluded to staff issues in that everyone in the building is not "on board" with technology and some staff members need to be "forced" into using it.

\section{Market trends of librarians or information specialists in madhya pradesh}

One of the reasons to keep up with the new trends of information society is to provide the students wider chance of employment and job opportunity. The teachers sensed that the job market is in need of information services staffs, but it also needs staff with new information technology competency. They also sensed that the up to cutting edge technology may bring good opportunity, but, the basic foundation of humanity and liberal arts and/or managerial skills will be needed after the entry level for LIS professional. Market trends of librarian or information specialists pointing at the "Information Contents" and its related knowledge and skills. With up to date information skills, the libraries may not be able to utilize their intelligence learned from schools, thus, recent graduates now turn their directions to corporate sector, private firms, and working as information specialist which pays better than libraries of different kind 


\section{CONCLUSION}

Since the authors are from MP state and have been involved in different LIS education activities, based on this some suggestions have been made to improve the quality of LIS education.

\section{These are}

- $\quad$ Latest IT infrastructure should be implemented in the computer laboratory of LIS department so that students will be well versed with those technologies and compete with today's LIS-IT market.

- The syllabus at all levels should be updated regularly and areas of Information science should be correlated with those of Library science

- The quality of teaching staff should be improved.

- Seminars, tutorials, assignments and field tours should be effectively integrated with curricula involving outside experts and agencies.

- To improve quality of research, talented scholars should be provided financial assistance by research organisations.

The ground reality of the present LIS education system in India indicates that the quality improvement is essential and unavoidable, not only for its survival but also for facing the major changes and challenges of today and tomorrow. Library schools in India need to look forward and take full advantage of the opportunities lying ahead of us. The use of information technology for training LIS students and professionals has become crucial for meeting the challenges of twenty first century. It has been predicted that a country that leads information revolution will prove to be more powerful than any other country. The significance of the role of library schools to train manpower for coming decades can contribute to the progress of the nation.

\section{REFERENCES}

1. Aula, A. (2003, November). Query Formulation in Web Information Search. In ICWI (pp. 403-410).

2. Bashir, S., Mahmood, K., \& Shafique, F. (2016). Internet use among university students: a survey in University of the Punjab, Lahore. Pakistan Journal of Information Management \& Libraries (PJIM\&L), 9(1).

3. Madnani, A., \& Batthini, G. (2003). Web search behaviour of LIS professionals of selected libraries of Ahmedabad and Gandhinagar: A study.

4. Chang, N. C., \& Perng, J. H. (2001). Information search habits of graduate students at Tatung University. The International Information \& Library Review, 33(4), 341-346.

5. Janesick, V. J. (1994). The dance of qualitative research design: Metaphor, methodolatry, and meaning.

6. Jansen, B. J., Spink, A., \& Saracevic, T. (2000). Real life, real users, and real needs: a study and analysis of user queries on the web. Information processing \& management, 36(2), 207-227.

7. Leu Jr, D. J. (2000). Our children's future: Changing the focus of literacy and literacy instruction. The Reading Teacher, 53(5), 424.

8. Leu, D. J., Kinzer, C. K., Coiro, J. L., \& Cammack, D. W. (2004). Toward a theory of new literacies emerging from the Interne and other information and communication technologies. Theoretical models and processes of reading, 5(1), 1570-1613.

9. Nachmias, R., \& Gilad, A. (2002). Needle in a hyperstack: Searching for information on the World Wide Web. Journal of Research on technology in Education, 34(4), 475-486.

10. The National Council of Teachers (NCTE) \& International Reading Association (IRA). (2002). Standards for the English Language Arts. Retrieved January 30, 2004, from http://www.ncte.org/library/files/Store/Books/Sample/46767Chap01.pdf

11. Pressley, M., \& Afflerbach, P. (1995). Verbal protocols of reading: The nature of constructively responsible reading. Hillsdael, NJ: Erlbaum.

12. RAND Reading Study Group. (2002). Reading for understanding: Towards and R\&D program in reading comprehension. Retrieved March 3, 2004. Available Online: http://www.rand.org/multi/achievementforall/reading/readreport.html

13. Sutherland-Smith, W. (2002). Weaving the literacy Web: Changes in reading from page to screen. The Reading Teacher, 55, 662-669.

14. Yin, R.K. (1989). Case study research: Design and methods (2nd. ed). Sage: Newbury Park, CA.

15. http://www.netugc.com/library-and-information-science-education-in-india 